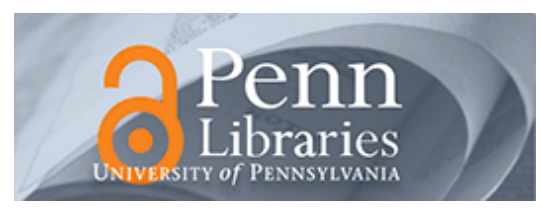

Manuscript Studies

Volume 2

\title{
An Investigation of the Relationship Between Prince Shōtoku's Shōmangyō-gisho and Two Dunhuang Buddhist Manuscripts: A Debate over Originality and Canonical Value
}

Mark Dennis

Texas Christian University, m.dennis@tcu.edu

Follow this and additional works at: https://repository.upenn.edu/mss_sims

Part of the Buddhist Studies Commons, Chinese Studies Commons, History of Religion Commons, History of Religions of Eastern Origins Commons, Japanese Studies Commons, and the Medieval Studies Commons

\section{Recommended Citation}

Dennis, Mark (2018) "An Investigation of the Relationship Between Prince Shōtoku's Shōmangyō-gisho and Two Dunhuang Buddhist Manuscripts: A Debate over Originality and Canonical Value," Manuscript Studies: Vol. 2 : Iss. 2 , Article 8.

Available at: https://repository.upenn.edu/mss_sims/vol2/iss2/8

This paper is posted at ScholarlyCommons. https://repository.upenn.edu/mss_sims/vol2/iss2/8

For more information, please contact repository@pobox.upenn.edu. 


\title{
An Investigation of the Relationship Between Prince Shōtoku's Shōmangyō-gisho and Two Dunhuang Buddhist Manuscripts: A Debate over Originality and Canonical Value
}

\begin{abstract}
This article investigates the relationship between two manuscript fragments discovered in Dunhuang, China referred to as Nai 93 and Tama 24, and the Shōmangyō-gisho, a Buddhist text written in classical Chinese attributed to Japan's Prince Shōtoku (574-622). Shōtoku is remembered in Japanese history as the country's first patriarch of Buddhism, revered for his patronage of the nascent faith and his great erudition. His studies under a Korean Buddhist monk led, according to early historical texts, to his composing the Shōmangyō-gisho and two other Buddhist commentaries that have been greatly valued throughout Japanese Buddhist history.

But the discovery of the Dunhuang manuscripts, which are quite similar to and predate Shōtoku's Shōmangyō-gisho, called into question the text's perceived value. The article examines scholarship on this discovery published in the late 1960s and 1970s, which represents the search for "the true record" of Prince Shōtoku, the dominant paradigm of the field. It is meant to be a preliminary piece to a more detailed study of the intellectual history and exegetical tradition of the three texts attributed to Shōtoku.
\end{abstract}

\section{Keywords}

China, Japan, Buddhism, Dunhuang, Shōmangyō-gisho, Shōtoku, Korea, monasticism, manuscript, fragment 


\section{MANUSCRIPT STUDIES \\ A Journal of the Schoenberg Institute for Manuscript Studies}

VOLUME 2, NUMBER 2

(Fall 2017)

Manuscript Studies (ISSN 2381-5329) is published semiannually

by the University of Pennsylvania Press

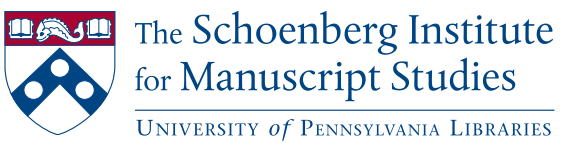




\section{MANUSCRIPT STUDIES}

VOLUME 2, N UMBER 2

(Fall 2017)

\section{ISSN 2381-5329}

Copyright (C) 2017 University of Pennsylvania Libraries and University of Pennsylvania Press. All rights reserved.

Published by the University of Pennsylvania Press, 3905 Spruce Street, Philadelphia, PA 19104.

Printed in the U.S.A. on acid-free paper.

Manuscript Studies brings together scholarship from around the world and across disciplines related to the study of premodern manuscript books and documents, with a special emphasis on the role of digital technologies in advancing manuscript research. Articles for submission should be prepared according to the Chicago Manual of Style, $16^{\text {th }}$ edition, and follow the style guidelines found at http://mss.pennpress.org.

None of the contents of this journal may be reproduced without prior written consent of the University of Pennsylvania Press. Authorization to photocopy is granted by the University of Pennsylvania Press for libraries or other users registered with Copyright Clearance Center (CCC) Transaction Reporting Service, provided that all required fees are verified with CCC and paid directly to CCC, 222 Rosewood Drive, Danvers, MA 01923. This consent does not extend to other kinds of copying for general distribution, for advertising or promotional purposes, for creating new collective works, for database retrieval, or for resale.

\section{SUBSCRIPTION INFORMATION:}

Single issues: $\$ 30$

Print and online subscriptions: Individuals: \$40; Institutions: \$90; Full-time Students: \$30 International subscribers, please add $\$ 18$ per year for shipping.

Online-only subscriptions: Individuals: \$32; Institutions: \$78

Please direct all subscription orders, inquiries, requests for single issues, address changes, and other business communications to Penn Press Journals, 3905 Spruce Street, Philadelphia, PA 19104. Phone: 215-573-1295. Fax: 215-746-3636. Email: journals@pobox.upenn.edu. Prepayment is required. Orders may be charged to MasterCard, Visa, and American Express credit cards. Checks and money orders should be made payable to "University of Pennsylvania Press" and sent to the address printed directly above.

One-year subscriptions are valid January 1 through December 31. Subscriptions received after October 31 in any year become effective the following January 1 . Subscribers joining midyear receive immediately copies of all issues of Manuscript Studies already in print for that year.

Postmaster: send address changes to Penn Press Journals, 3905 Spruce Street, Philadelphia, PA 19104.

Visit Manuscript Studies on the web at mss.pennpress.org. 


\section{MANUSCRIPT STUDIES}

\section{A Journal of the Schoenberg Institute for Manuscript Studies}

VOLUME 2, N UMBER 2

\section{Articles}

Statim Prosequi: An Index as a Product, Instrument, and Medium of the Medieval Franciscan Inquisition in Tuscany

A Tool for Exemplary Pastoral Care: Three Booklets of the

Edwardes Manuscript in Context

HANNAH WEAVER

Conversational Lollardy: Reading the Margins of

MS Bodley 978

Elizabeth SCHIRMER

"My Written Books of Surgery in the Englishe Tonge":

The London Company of Barber-Surgeons and the Lylye of Medicynes

ERIN CONNELLY

The Two Yohannases of Santo Stefano degli Abissini, Rome: Reconstructing Biography and Cross-Cultural Encounter through Manuscript Evidence

Textual Contents of Pāli Samut Khois: In Connection with the Buddha's Abhidhamma Teaching in Tāvatimsa Heaven Toshiya Unebe

The Western Manuscript Collection of Alfred Chester Beatty (ca. 1915-1930) 
Manuscript Studies, Vol. 2 [2018], Iss. 2, Art. 8

iv | Journal for Manuscript Studies

The St. Chad Gospels: Diachronic Manuscript Registration and Visualization

Stephen Parsons, C. Seth Parker, and W. Brent Seales

\section{Annotations}

An Investigation of the Relationship between Prince Shōtoku's Shōmangyō-gisho and Two Dunhuang Buddhist Manuscripts: A Debate over Originality and Canonical Value Mark Dennis

The Glossa Ordinaria Manuscripts of the Biblioteca Capitolare of Monza

E. ANn MatTer 508

The Summula de Summa Raymundi in Gordan MS 95, Bryn Mawr College

Tномаs IzBicki 524

A Newly Discovered Manuscript of the Historia de los Reyes Moros de Granada by Hernando de Baeza

María Mercedes Delgado Pérez 540

\section{Reviews}

Albert Derolez. The Making and Meaning of the Liber Floridus: A Study of the Original Manuscript, Ghent, University Library MS 92

Mary FrankLin-Brown 569

Bent Lerbæk Pedersen. Catalogue of Yao Manuscripts ADAm SMith

T. L. Andrews and C. Macé, eds. Analysis of Ancient and Medieval Texts and Manuscripts: Digital Approaches 
Dennis: An Investigation of the Relationship Between Prince Sho?toku's Sh

Contents | v

Elizabeth Solopova. Manuscripts of the Wycliffite Bible in the Bodleian and Oxford College Libraries

KathleEn Kennedy

Colour: The Art and Science of Illuminated Manuscripts

Nicholas Herman

List of Manuscripts Cited 


\title{
An Investigation of the Relationship Between Prince Shōtoku's Shōmangyō-gisho and Two Dunhuang Buddhist Manuscripts
} A Debate over Originality and Canonical Value

\author{
MARK DENNIS \\ Texas Christian University
}

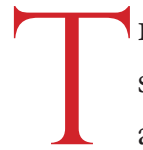

his article investigates the relationship between two manuscript fragments discovered at Dunhuang, ${ }^{1}$ referred to as Nai 93 and Tama 24, and the Shömangyō-gisho, a Buddhist text written in classical Chinese that has traditionally been attributed to Japan's Prince Shōtoku (574-622). The determination of Fujieda Akira and Koizumi Enjun that the text attributed to Shōtoku postdated and was strikingly similar to these manuscripts caused a heated scholarly debate. Indeed, much intellectual effort was spent in the late 1960s and 1970s seeking to clarify the texts' relationship because the Shömangyo-gisho's originality was central to its perceived value and canonical status. This scholarship, which continues in the present, can be viewed as part of the broader search for "the true record" (Japanese, jitsuroku) of Shōtoku studies, which informs much, but not all,

1 Dunhuang is located in northwest China's Gansu province. In 1900, the Daoist monk Wang Yuanlu discovered a large cache of manuscripts in the Mogao caves. Those manuscripts included a large number of Buddhist texts, many composed in classical Chinese, but also manuscripts written in other languages representing Buddhism and other religious traditions. See http://idp.bl.uk for a link to the International Dunhuang Project (IDP). 
scholarship on the Shömangyō-gisho and two other Buddhist commentaries attributed to the prince.

As background, Prince Shōtoku appears in the Nibon shoki (compiled in 720) and other early texts as an accomplished politician and key patron of the nascent Buddhist community in Japan, which was beginning to develop with the support of continental immigrants. These texts credit him with composing a seventeen-point constitution and promoting diplomatic contacts with the Chinese dynasties and Korean kingdoms from which Buddhist teachers brought their texts and traditions. To promote the local assimilation of Buddhism, Shōtoku is said to have donated land to the community, built temples, and collected texts written in classical Chinese. He is also described as a brilliant and devout practitioner of the new faith who quickly mastered its teachings under the tutelage of Hyeja, a Buddhist monk from Paekche (one of the Three Kingdoms of Korea). Although differing in details, these texts mostly agree that Shōtoku's tutelage under Hyeja led to lectures by the prince on key Buddhist texts at court; those lectures served, in turn, as the basis for his composition of the Shömangyō-gisho and two other Buddhist texts known as the Sangyō-gisho (Commentaries on the Three Sūtras).

In this earliest period of Japanese Buddhism, the Sangyō-gisho were quickly recognized as valuable religious texts; their value was evident in, for example, their inclusion in early versions of the Buddhist canon. Although Chikō (708?-780?), Saichō (767-822), and other figures from this period used the Sangyo-gisho texts to understand and illuminate other Buddhist texts, it seems that the very act of their composition by a local Japanese author was crucial to their perceived value. Some five hundred years after Shōtoku's death, Gyōnen, a Kamakura-era Buddhist monk of the Kegon school, wrote the first detailed treatises on each of the Sangyo-gisho texts, thereby inaugurating an exegetical tradition that survives into the present day as one key element of Shōtoku studies.

\section{The Search for the "True Record"}

A key point in the modern period of Shōtoku studies is marked by the 1905 publication of Kume Kunitake's Jōgū Taishi Jitsuroku (The true record of 
Jōgū Taishi). ${ }^{2}$ Since its publication, scholars, artists, novelists, and others have produced a massive body of Shōtoku-related materials, including highly technical scholarly studies as well as novels and manga, television dramas, and online blogs that depict, discuss, and debate key events from Shōtoku's life, including his patronage of Buddhism and study of Buddhist teachings with Hyeja. ${ }^{3}$

The focus of many of these scholarly studies has been recovering the "true record" of Shōtoku by sifting fact from historical embellishment. This goal has also sharply defined Sangyö-gisho scholarship, a subdiscipline within Shōtoku studies, wherein most scholars fall into one of two main camps known as the true-composition hypothesis and the false-composition hypothesis. ${ }^{4}$ Proponents of the former position have expended great intellectual effort trying to prove not only that Shōtoku authored the three Sangyogisho texts, but also that they are original works of a brilliant Japanese mind, certainly deserving of their valued canonical status. Hanayama Shinshō, Kanaji Isamu, and other scholars from this camp have tried to defend the texts' canonical status by revealing their uniqueness, lucidity, and profundity, which requires, in part, detailing their distinctiveness from intellectual models and predecessors. In the case of the Shomangyo-gisho, for instance, these scholars have scrutinized the relationship between Shōtoku's Shömangyō-gisho and a text it refers to regularly as the bongi, or "model text," and also its relationship to a group of texts it refers to as "other commentaries."

Much true-composition-hypothesis scholarship has been devoted to responding to the assertions of Tsuda Sökichi and his false-compositionhypothesis successors who reject Shōtoku's authorship of the three Sangyogisho commentaries. Their scholarship represents one part of a broader

2 Jōgū Taishi is one of Shōtoku's names. After publishing Jōgū Taishi jitsuroku in 1905 (Osaka: Sekibunsha), Kume published Shōtoku Taishi jitsuroku in 1919 (Tokyo: Heigo Shuppansha), which was reprinted in 1942 (Tokyo: Ryūginsha).

3 Examples include a three-hour NHK drama titled Shōtoku Taishi that was broadcast in 2001 and a large number of manga either dedicated to the prince or discussing his contribution to, for example, the history of Japanese Buddhism. There are also Shōtoku Taishi T-shirts, figurines, and jigsaw puzzles, among other such items of popular culture.

4 There is a third position that posits joint authorship in which Shōtoku played some sort of meaningful role in their composition. See note 9. 
attack on the received narrative of Shōtoku as a pivotal figure of early Japanese history. Tsuda and other proponents of this position offer evidence they claim proves Shōtoku could not possibly have written the Sangyō-gisho texts, arguing instead that they were written by a continental author or authors and brought to Japan, or were composed solely or jointly by an immigrant monk or monks from the Korean peninsula residing in Japan, after which they were falsely attributed to Shōtoku. Since the publication of Tsuda's scholarship in the 1930s and 1940s, Fujieda Akira, Koizumi Enjun, and other false-composition-hypothesis scholars have elaborated and refined his assertions.

\section{The Discovery of the Dunhuang Manuscripts}

While rejecting Shōtoku's authorship of the three Sangyō-gisho texts, Fujieda and Koizumi have also challenged the Shōmangyō-gisho's originality by revealing its high degree of correspondence with Nai 93 and Tama 24the two Dunhuang manuscripts mentioned above, which, scholars agree, pre-date Shōtoku's text. ${ }^{5}$ Yang Yufei notes that Nai 93 is thirty-six pages in

5 For a discussion of these findings, see Fujieda Akira, "Hokuchō ni okeru Shōmangyō no denshō," Tōbō Gakkai 40 (March 1969): 325-49; Fujieda Akira, "Shōmangyō-gisho," in Nibon shisō taikei 2: Shōtoku Taishishū, ed. Ienaga Saburō (Tokyo: Iwanami shoten, 1975), 484-544; Fujieda Akira and Koizumi Enjun, "Sankō E hon Shōman-gisho hongi tonkōhon," in Nihon shisō taikei, vol. 2: Shōtoku Taishishū, ed. Ienaga Saburō (Tokyo: Iwanami shoten, 1975), 429-62; and Koizumi Enjun, “Tonkōhon Shōmangisho hongi," Shōtoku Taishi Kenkyū 5 (1969): 59-141. For a discussion of the relationship between the Shomangyō-gisho, the Dunhuang manuscripts, and the hongi from the perspective of the true-composition hypothesis, see Kanaji Isamu, "Tonkō hakken no Shōmangyōsho (Nai 93) to Shōmangyō-gisho to no hikaku: omo toshite bunshō kadan ni tsuite," Indogaku bukkyōgaku kenkyū 18, no. 2 (1970): 835-841; Kanaji Isamu, "Shōmangyō-gisho to Shōmangyōsho (Nai 93) to no hikaku kenkyū-2: omo toshite sono gakkei ni tsuite,” Indogaku bukkyōgaku kenkyū 18, no. 2 (1970): 270-273; Hirakawa Akira, "Shōmangyō-gisho to Nai 93 to no kankei ni tsuite," in Shōtoku Taishi ronshū, ed. Kokumin Bunka Kenkyūkai Shōtoku Taishi Kenkyūkai (Kyoto: Heirakuji shoten, 1971), 207-30; Kanaji Isamu, "Shōmangyō-gisho no 'bongi' ni tsuite," Shōtoku Taishi Kenkyū 7 (1972): 25-38; Fujii Kyōkō, "Shōmangyō-gisho hongi," in Shōtoku Taishi jiten, ed. Ishida Hisatoyo (Tokyo: Kashiwa Shobō, 1997), 142-43. 
length but is missing material that would have appeared at the beginning of the manuscript, while Tama 24 is thirteen pages and corresponds to material from the last section of Nai 93. He describes both manuscripts as being skillfully brushed in gyōsho, a semi-cursive script. ${ }^{6}$

The revelation of this high degree of correspondence between the Shömangyo-gisho and these Dunhuang manuscripts is considered by scholars to be one of the most important modern discoveries in Sangyō-gisho studies. ${ }^{7}$ Its significance is attested to by the flurry of subsequent scholarly activity seeking to determine the precise relationship between these manuscripts and the Shömangyō-gisho.

In their initial findings, Fujieda and Koizumi identified the Dunhuang manuscripts as the bongi of the Shömangyo-gisho, and thus referred to them as the "Shōmangyō-gisho hongi" (the model text of the Shömangyō-gisho). ${ }^{8}$ But further study revealed the existence of material in the Shömangyo-gisho that differed from Nai 93-Tama 24, and thus seemed to point to a different bongi pre-dating the Dunhuang manuscripts. These differences led them to conclude that Nai 93-Tama 24 and the Shomangyo-gisho were composed

6 See Yang Yufei, "Chūgoku Nanbokuchō Jidai ni okeru Bonnōron: Shōmangyō no Shochūshakusho o Chūshin Toshite,” Sengokuyama Journal of Buddbist Studies 8 (2016): 153-54.

7 Its importance is evident in other ways: for example, Kanaji Isamu notes that these findings were reported in the 28 August 1968 edition of the Yomiuri Shimbun, one of the main Japanese daily newspapers. And the preface to one of the critical editions of the Shomangyogisho notes that its production was motivated, in part, because none of the previous editions had been produced after the publication of Fujieda's and Koizumi's research. See Kanaji, "Shōmangyō-gisho" no shisōteki kenkyū (Tokyo: Sankibō busshorin, 1971), 23.

8 Koizumi's reconstruction of Nai 93 can be found in "Tonkōhon Shōmangisho hongi," Shōtoku Taishi kenkyū 5 (1969): 59-141. Fujieda notes that although Shöman-gisho would have been a more appropriate title, since other commentaries were already known by that name, the former was selected (Fujieda, "Shömangyō-gisho," 487). Based on the brush work, Koizumi concludes that both manuscripts are sixth-century texts from the Northern Dynasties period, but concedes that while it is possible they were transmitted from the south, they were, at a minimum, copied and read in the north. Although there are differences between Nai 93 and Tama 24, Koizumi notes that the meaning of the text is not significantly altered by them and that they are clearly copies of the same text. Most of these differences are related to specific characters: variants that have the same sound (Japanese, ontsī) or the omission of characters in one or the other manuscript (Japanese, datsuji). Koizumi, “Tonkōhon," 11. 
based on the same hongi, which Koizumi labels the "hongi genpon" (source text of the model text). ${ }^{9}$

Based on his reconstruction of Nai 93, the more complete of the two manuscripts, Koizumi estimates that of the Shomangyo-gisho's roughly 1,400 lines, only about three hundred differ with these manuscripts, and thus over three-quarters of the Shomangyo-gisho was taken directly from the bongi. ${ }^{10} \mathrm{He}$ and Fujieda thus argue that because the Shomangyo-gisho relies so heavily on this earlier text, it exhibits very little originality regardless of the latter's identity and their precise relationship. This high degree of correspondence between the Dunhuang manuscripts and the Shömangyō-gisho leads Fujieda to conclude that the latter should be understood as no more than a "revised text." ${ }^{11}$ These sorts of texts, he notes, are not uncommon in the East Asian commentarial tradition and function mainly "to supplement, correct, and abbreviate their root texts." ${ }^{2}$ Fujieda further questions the originality of the Shomangyo-gisho by noting that over half its differences with Nai 93-Tama 24 are based on short summaries of the succeeding section that appear at the beginning of section breaks in the Shomangyo-gisho, but which are not found in the Dunhuang manuscripts. ${ }^{13}$

\section{Koizumi Enjun, “Tonkōhon,” 11.}

10 Koizumi Enjun, “Tonkōhon,” 9.

11 Fujieda, "Shōmangyō-gisho," 504. In a similar way, Watanabe Shōkō describes the three commentaries as "notebooks," which could have been written by a student studying with a Chinese master. See Watanabe, "Sangyō-gisho no sakusha mondai: nihon bukkyō no ayumi" (6), Daiborin 24-28 (1957): 154. In assessing the originality of the Sangyō-gisho, Hirai Shun'ei writes, "Because the Sangyo-gisho relies on the hongi for over two-thirds of its interpretations, and also draws on the [thought of scholars cited in the] work of Jizang, [these commentaries] should be considered patchworks. And because there are so few quotations of the sütras and other commentaries, they are basic texts that are rather unsophisticated. In this way, as is pointed out by Ōno [Tatsunosuke], it would not be unusual if they were produced in the Asuka period. But in that case, just as is asserted by the false-composition-hypothesis, it is with the assumption that they were not the work of Shōtoku Taishi alone." Hirai Shun'ei, "Sangyō-gisho no seiritsu to Kichizōso," in Sanron kyōgaku no kenkyū, ed. Hirai Shun'ei (Tokyo: Shunjūsha, 1990), 533.

12 Fujieda, "Shōmangyō-gisho," 504.

13 Fujieda, "Shōmangyō-gisho," 501-4. 
Manuscript Studies, Vol. 2 [2018], Iss. 2, Art. 8

Dennis, Prince Shōtoku's Shōmangyō-gisho and Two Manuscripts

\section{The True-Composition-Hypothesis Response to the Dunhuang Manuscripts}

While Hanayama, Kanaji, and other true-composition-hypothesis scholars acknowledge these relationships and the Shömangyō-gisho's reliance on its intellectual predecessors, they have sought with great effort to prove that it is not, as Fujieda and Koizumi argue, simply a rehashing of the Dunhuang manuscripts and the bongi, but a valuable religious work in its own right. If it were reclassified as no more than an unoriginal copy, this would be seen as a crucial blow to the large corpus of scholarship extolling Shōtoku's great intellect and position as first patriarch of the nascent Japanese Buddhist tradition. Moreover, this proof is, naturally, crucial to maintaining the text's value because even if it were proven that Shōtoku had composed it, if it is little more than a restatement of the bongi and other commentaries, its value would diminish significantly. To this end, they stress that although the Shömangyō-gisho is similar in some ways to Nai 93-Tama 24, and possibly to an even earlier hongi, it is also true that a number of its passages do not agree with these manuscripts, as some appear to address the work of Chinese Buddhist exegetes whose work is lacking in the Dunhuang manuscripts, while still others are unique to the Shomangyō-gisho.

Hanayama argues that while Shōtoku relies on the hongi, he does not "follow it blindly," ${ }^{14}$ and that although he accepts some of the interpretations of his Chinese predecessors, he criticizes them at other times, and thus exhibits a "critical attitude" toward the work of these exegetes. $\mathrm{He}$ writes, "Based on my research into the thought, sentences, language, and so forth of the entire Shomangyō-gisho, and on comparisons to other extant commentaries [on the Śrimāla $\bar{a}-s \bar{u} t r a]$, I estimate there to be approximately one hundred eighty passages that reveal the author's own interpretations." ${ }^{15}$

14 Hanayama Shinshō, Shōmangyō-gisho no Jōgū ōsen ni kansuru kenkyū (Tokyo: Iwanami Shoten, 1944), 405. In this regard, he cites Shōtoku's use of phrases such as "I believe that these views are insufficient," among others, as proof of Shōtoku's "critical attitude" (313).

15 Hanayama, Jōgūōsen, 408. 
For Hanayama, therefore, although the text attributed to Shōtoku participates in and transmits the Chinese exegetical tradition, it represents a crucial, locally produced interpretive development. It is thus justified as an object of value and reverence, and worthy of detailed exegesis in the model established in the Kamakura era by Gyōnen.

And while Kanaji also acknowledges that the Shomangyō-gisho relies on this body of previous scholarship, he too argues that it exhibits unique interpretations, ${ }^{16}$ writing:

When we think in these terms, it is not then so important [to determine] to what extent the interpretations of the hongi [appear] in the Shomangyo-gisho and to what degree they are the individual [ideas] of [Shōtoku] Taishi. Since there is no meaning to the gisho apart from the hongi, a more important concern is how the gisho was composed based on [Shōtoku's] interpretation of the Śrimālā-sūtra. If we search too deeply in this way, we will not only lose the vitality of the gisho, it is also possible that our understanding of the sūtra itself will become muddied. We must seek, therefore, to understand how, based on the hongi, Shōtoku read and interpreted the sūtra, and then to make his way of reading and accepting it our own as we too taste again the sūtra itself. If we do not, we have not truly read the gisho. And in this way, there are no obstacles to taking the gisho as a whole as the work of [Shōtoku] Taishi. That is, [while it is true] he used the hongi to understand the sūtra, it is still his own work because it is not simply [the repetition of the hongi's ideas]; rather, [Shōtoku's commentary] surpasses the bongi by putting forth such new interpretations. ${ }^{17}$

16 Kanaji discusses what he describes as the Sangyo-gisho's "special characteristics" in a number of articles and books, including Shōtoku Taishi kyōgaku no kenkyū: Sangyō-gisho ni tsuite (Osaka: Shōtoku Taishikai, 1962), 27-52, 194-217. See also Kanaji’s Jōgūōsen "Sangyō-gisho" no Shomondai (Kyoto: Hozokan, 1985), 75-94. See also Watanabe Kōjun, "Shōmangyō-gisho no tokuchō ni tsuite," in Shōmangyō-gisho ronshū, ed. Nihon Bukkyō Genryū Kenkyūkai (Kyoto: Nihon Bukkyō Genryu Kenkyūkai, 1965), 126-32.

17 Kanaji, "Shōmangyō-gisho" no shisoteki kenkyū, 24. 
In this way, the Shomangyō-gisho participates in the East Asian commentarial tradition but exhibits a "progressive, interpretive step forward."18 But even though Kanaji argues it is not so important to separate the interpretations of the bongi from those of the Shomangyō-gisho, the great intellectual effort that he, Hanayama, and others have made to prove the latter's uniqueness seems at odds with this claim. Kanaji also observes that determining the text's authorship is a complex project, and writes, "Even if we knew that a single individual wrote the Sangyō-gisho, proving conclusively that it was Shōtoku Taishi is difficult. Thus, even Hanayama's work must be understood as a hypothesis." ${ }^{19}$

These comments raise the following questions that I plan to pursue as part of a broader project on the intellectual history and exegetical tradition of Sangyo-gisho studies. Given this complexity and these seemingly inconclusive results, why do these scholars persist in searching for the true record? And in seeking to prove or disprove Shōtoku's authorship of the text and its inherent originality in their pursuit of the "true record," what intellectual roads and angles of critical vision have been foreclosed? This project will take the form of a monograph, in which I will bring to bear scholarship on authorship, canon, and value to investigate these questions. One section of the monograph will investigate how more recent scholarship has dealt with the Dunhuang discovery.

18 Kanaji, "Shōmangyō-gisho" no shisoteki kenkyū, 23.

19 Kanaji, "Sangyō-gisho" no shomondai, 64. 


\section{LIST OF MANUSCRIPTS CITED}

Baltimore, Walters Art Museum

W 751: 451, 470

W 759-62: 474

W 777: 473

Bangkok, Wat Hua Krabu

Manuscript: 431, 432 fig. 1

Berlin, Staatsbibliothek

HS 241: 480

Birmingham, Barber Institute

No. 397: 479

Boston, Boston Public Library

MS 1532: 473

Brussels, Bibliothèque Royale

MS IV 191: 481

MS IV 542: 478

Bryn Mawr, PA, Bryn Mawr College

Gordan MS 95: 527-28, 527 fig. 1, 528

nn. 15-16

Cambridge, MA, Harvard University,

Houghton Library

MS Richardson 17: 482

MS Richardson 26: 471

MS Typ 141: 476

MS Typ 143: 480

MS Typ 200: 472

MS Typ 201: 474

MS Typ 202: 472

MS Typ 213: 478

MS Typ 217: 482

MS Typ 228: 474

MS Typ 703: 476
Cambridge, UK, Corpus Christi College

MS 4: 585

MS 32: 338, 338 n. 25, 343 n. 34, 355 n. 61

Cambridge, UK, Fitzwilliam Museum

MS 251, fol. 15r: 585

MS 276: 586

MS 159: 587

MS 330: 472, 585

MS 375: 462, 478

Collegeville, MN, Saint John's University,

Ethiopian Manuscript Microfilm Library

MS no. 4553: 414 n. 69

Cologne, Historisches Archiv

Best. 7010-293: 585

Cologny, Fondation Martin Bodmer

Cod. Bodmer $14: 476$

Cod. Bodmer 68: 470

Cod. Bodmer 104: 480

Cod. Bodmer 128: 481

Cod. Bodmer 139: 481

Cod. Bodmer 183: 474

Dublin, Chester Beatty Library

Thai MS 1341: 432

Thai MS 1343: 433

W 017: 471

W 029: 471

W 040: 472

W 043: 472

W 061: 474

W 066: 474

W 076: 457 fig. 3, 475

W 078: 475 
Manuscript Studies, Vol. 2 [2018], Iss. 2, Art. 8

\section{Journal for Manuscript Studies}

W 080: 475

W 082: 453, 454 fig. 1, 458, 479

W 089: 478

W 094: 479

W 099: 482

W 107: 477

W 108: 477

W 113: 477

W 122: 477

W 124: 476

W 127: 476

W 188: 480

W MS 103 (formerly; now dismembered): 455 fig. 2, 456

Dunhuang

Nai 93: 499, 502-7, 503 n. 8

Tama 24: 499, 502-7, 503 n. 8

Florence, Bibl. Medicea Laurenziana

MS Or. 148: 423

Geneva, Bibliothèque de Genève

Comites Latentes MS 15: 474

Comites Latentes MS 38: 479

Ghent, Universiteitbibliotheek

MS 92: 569

Göttingen, Niedersächsische Staatsund-Universitätsbibliothek

MS Uffenb. 51 cim.: 585

The Hague, Koninklijke Bibliotheek

MS 135 E 23: 478

MS 135 J 8: 477

The Hague, Museum Meermanno-

Westreenianum

MS 10 B 23: 355 n. 61

Hildesheim, Dombibliothek

MS St Godehard 1: 355 n. 61

Jerusalem, National Library of Israel

Yah MS Var 4: 467 n. 96, 478

Yah MS Var 8: 467 n. 96, 477

Yah MS Var 9: 467 n. 96, 478
Yah MS Var 11: 467 n. 96, 477

Yah MS Var 12: 467 n. 96, 482

Yah MS Var 13: 475, 467 n. 96

Yah MS Var 14-15: 476, 467 n. 96

Yah MS Var 16: 467 n. 96, 481

Kew, The National Archives

PROB 11/49/251: 375 n. 15-16, 378 n. 31

PROB 11/116/532: 377 n. 24

Lichfield, Cathedral Library

MS 1: 483-98

Lisbon, Museu Calouste Gulbenkian MS LA 210: 479

London, British Library

Add. 38662: 296-327, 296 n. 1, 299 fig. 1, 306 n. 26

Add. 38663: 296-327, 296 n. 1, 299 fig. 2, 306 n. 26

Add. 38664: 296 n. 1

Add. 40142: 296-327, 296 n. 1, 301 fig. 3, 306 n. 26

Add. 40143: 296 n. 1

Add. MS 43460: 469

Add. MS 48985: 474

Add MS 52660: 452 n. 33-34, 462 n. 70, 466 n. 90-91

Add. MS 52653: 446 n. 6, 447 n. 7, 449 n. 16-17

Add. MS 52656: 458 n. 51

Add. MS 52657: 458 n. 49, 472 n. 99, 476

n. 106

Add. MS 52658: 452 n. 31

Add. MS 52662: 459 n. 55, 461 n. 67, 462

n. 68

Add. MS 52670: 460 n. 58, 462 n. 72 and 75

Add. MS 52692: 462 n. 73

Add. MS 53652: 445 n. 1

Cotton MS Nero A XI: 311

Egerton MS 3055: 472

Egerton MS 3088: 473

Egerton MS 3089: 471 
Dennis: An Investigation of the Relationship Between Prince Sho?toku's Sh

List of Manuscripts Cited | 591

MS Harley 1862: 335 n. 23

MS. Harley 3698: 390 n. 63

MS Harley 3915: 585

MS Laud Misc. 511: 336 n. 24, 347

MS Royal 15 D 1: 355 n. 61

MS Royal 17: 328 n. 1

MS Royal 17 C.xxxiii (Royal C): $328 \mathrm{n}$.

1, 333, 335-36, 336 fig. 1, 346 n. 37, 365

n. 67

MS Royal 17 D.viii (Royal D): 333, 335-

37, 337 fig. 2, 346 n. 37, 348 n. 46, 349

n. 47,352 n. 50,365 n. 67

MS. Sloane 334: 390 n. 63

MS. Sloane 512: 390 n. 63

OR. 13703: 433, 434 fig. 2

Or. 16552: 434

Yates Thompson MS 7: 450 n. 19

London, London Metropolitan Archives, Guildhall Library

MS. 5265/1: 376 n. 17, 377 n. 25, 380 n. 36

MS. $9051 / 5$ : 378 n. 30,385 n. 50

MS. $9171 / 15: 378$ n. 28

London, Quaritch Archives

Commission Book for 1914-1917: 446

n. 2-3

Commission Book for 1917-1920: 450

n. 19 and 21

Commission Book for 1921-1926: 461

n. $62-63$

London, Victoria and Albert Museum

MS 16: 472

MS Ludwig V 6: 475

MS Ludwig IX 3.: 474

P.159-1910: 585

Los Angeles, The J. Paul Getty Museum MS 48: 478

MS Ludwig XI, 1: 480

Madrid, Biblioteca Nacional

MSS/11267/21: 542
Milan, Biblioteca Nazionale Braidense

AC IX 36: 473

Monza, Biblioteca Capitolare

Monza a-3/10: 514 n. 24

Monza a-3: 513 n. 18, 514, 514 n. 21, 515 n. 27

Monza a-4: 513 n. 18

Monza a-5: 513 n. 18, 515 n. 29

Monza a-6: 513 n. 19, 516 n. 30, 518-19

Monza a-7: 513 n. 19

Monza a-8: 513 n. 18

Monza a-9: 513 n. 19

Monza a-10: 513 n. 19, 514 n. 20, 516

n. 31,517 fig. 2

Monza a-11: 513 n. 19, 516 n. 31

Monza a-12: 513 n. 18

Monza a-13: 513 n. 19, 516 n. 31

Monza a-14: 513 n. 18-19, 516 n. 31

Monza a-15: 513 n. 17

Monza a-16: 513 n. 19, 516 n. 32

Monza a-17: 513 n. 19, 516 n. 31

Monza a-18: 513 n. 19, 516 n. 32

Monza a-19: 513 n. 19

Monza a-20: 513 n. 18

Monza a-21: 513 n. 18

Monza a-22: 513 n. 18, 514 n. 24, 515 n.

27, 516 n. 30, 519

Monza a-23: 513 n. 19, 514 n. 24, 515

n. 27

Monza a-24: 513 n. 18

Monza a-25: 513 n. 18, 514 n. 24, 515

n. 27

Monza a-26: 513 n. 19

Monza a-27: 513 n. 16

Monza b-1: 513 n. 16

Monza b-2: 513 n. 19, 516 n. 31

Monza b-3: 513 n. 19, 515, 515 n. 25

Monza b-4: 513 n. 19, 515, 515 n. 28

Monza b-5: 513 n. 19, 514 n. 24, 515

n. 27

Monza b-7: 513 n. 16

Monza b-9: 514 n. 24, 515 n. 27

Monza e-4: 513 n. 18, 516 n. 31 
Manuscript Studies, Vol. 2 [2018], Iss. 2, Art. 8

\section{Journal for Manuscript Studies}

Monza e-5: 513 n. 18

Monza e-6: 513 n. 17 and 19

Monza e-8: 513 n. 19

Monza e-9: 513 n. 16

Monza e-11: 513 n. 18

Monza e-13: 513 n. 19, 516 n. 31, 519

Monza i-11: 513 n. 17

Münster, Bibliothek Universität Münster

MS NR 1003: 481

New Haven, Yale University, Beinecke Rare

Book and Manuscript Library

MS 111: 480

MS 400: 449, 449 n. 18, 479

MS 402: 471

MS 407: 475

MS 413: 470

MS 414: 472

MS Osborn fa42: 472

New York, Metropolitan Museum of Art 1997.320: 473

New York, Morgan Library and Museum ARC 1310: 458 n. 50, 463 n. 78

MS G 17: 471

MS M 777: 450 n. 21, 471

MS M 808: 473

MS M 826: 469

MS M 855: 473

MS M 860: 470

MS M 862: 470

MS M 883: 471

MS M 939: 472

MS M 962: 471

New York, New York Public Library

MS M 834: 479

MS M 1004: 479

MS M 1110: 479

Spencer MS 27: 451, 480-81

Spencer MS 28: 480

Spencer MS 29: 477

Spencer MS 64: 481

Thai MS.6: 432
Oslo, Schøyen Collection

MS 50: 470-71

Oxford, Bodleian Library

Digby 23: 322, 322-23 n. 87

MS 48: 326 n. 100

MS. Ashmole 1505: 369-91, 371 fig. 1, 272 fig. 2, 373 figs. 3-4, 374 fig. 5

MS Bodley 978: 328-68, 328 n. 1, 341 n. 33, 342 fig. 3, 343 fig. 4, 344 fig. 5, 346 n. 37, 347 n. 43, 348 n. 46, 349 fig. 6, 349 n. $47-48,352$ n. $50-51,353$ n. 55, 357 fig. 7 , 358 n. 64,361 fig. 8,361 n. 67,362 n. 68 , 366 n. 78,368 n. 80

MS Pali a.27 (R): 428 n. 3, 431, 444 MS Phillipps-Robinson C 719: $450 \mathrm{n}$. 22-24, 451 n. 25-26 and 29, 458 n. 47, 459 n. $53-54$

Oxford, Lincoln College

MS Lat. 150: 473

Oxford, Trinity College

MS 93: 332 n. 14, 583

Oxford, Worcester College

MS E. 10. 7: 583

Paris, Bibliothèque nationale de France MS Éth. 35: 415 n. 71

MS fr. 24766: 300, 300-301 n. 7, 302 fig. 4, 304-5, 309

MSS n.a.f. 15939-15944: 475

MS n. a. lat. 3115: 478

MS n. a. lat. 3119: 480

Paris, l'École française d'Extrême-Orient EFEO 39: 434, 435 fig. 3

EFEO 40: 432

Phillipps, Sir Thomas, collection of MS 125: 474

MS 134/3948: 475

MS 137: 480

MS 240: 477

MS 250: 480

MS 385: 472 
Dennis: An Investigation of the Relationship Between Prince Sho?toku's Sh

List of Manuscripts Cited | 593

\begin{tabular}{|c|c|}
\hline MS 389: 470 & MS 12348: 471 \\
\hline MS 390: 470 & MS 14122: 451, 470 \\
\hline MS 437: 477 & MS 21948: 471 \\
\hline MS 934/2708: 471 & \multirow{6}{*}{$\begin{array}{l}\text { Private Archive of the Escalante family } \\
\text { Historia de los reyes moros de Granada: } \\
\text { 544-67, } 548 \text { fig. } 1,550 \text { n. } 18 \text { and } 22-23 \text {, } \\
551 \text { fig. } 2,551 \text { n. } 24,553 \text { fig. 3, } 554 \text { fig. } 4 \text {, } \\
555 \text { fig. } 5\end{array}$} \\
\hline MS 1036: 473 & \\
\hline MS 1092: 472 & \\
\hline MS MS 1347: 452 & \\
\hline MS 1798: 456, 459, 475 & \\
\hline MS 2164: 458 & \\
\hline MS 2165/21787: 470 & Petchaburi, Thailand, Wat Lat \\
\hline MS 2251: 477 & Manuscript: 433 \\
\hline MS 2506: 463, 476 & \multirow{3}{*}{$\begin{array}{l}\text { Philadelphia, Philadelphia Museum of Art } \\
\text { 1945-65-6: } 480\end{array}$} \\
\hline MS 3009: 482 & \\
\hline MS 3010: 451, 480 & \\
\hline MS 3075: 470 & Philadelphia, University of Pennsylvania \\
\hline MS 3339: 474 & Rare Book and Manuscript Library \\
\hline MS 3344: 471 & MS Codex 730: 528, 530 fig. 3, 531, 531 \\
\hline MS 3383: 474 & nn. $20-22,532$ nn. $23-26$ and $30-34$, \\
\hline MS 3502: 459, 477 & 533 nn. $37-39,41,43-47,49$ and 53, \\
\hline MS 3535: 471 & 534 nn. $56-60,62-63$ and $65-73,535$ \\
\hline MS 3633: 452 & nn. $74-75,80-82$ and 84,536 n. 85,87 \\
\hline MS 3674: 471 & and $90-95,537$ nn. $96-99,101-2$ and \\
\hline MS 3897: 474, 477 & $104-113,538$ nn. $119-22,124-25,128-$ \\
\hline MS 3948: 456 & 33 and $135-6,539 \mathrm{nn} .137-40,145-50$ \\
\hline MS 4259: 473 & and 152 \\
\hline MS 4448: 473 & MS Codex 741: 528, 529 fig. 2, 531, 531 \\
\hline MS 4597: 472 & nn. $20-22,532$ nn. $23-30,32$ and 35,533 \\
\hline MS 4600: 474 & nn. $36,40,42,46-48$ and $50-52,534 \mathrm{nn}$. \\
\hline MS 4769: 471 & $54-58,60-67$ and $71,535 \mathrm{nn} .74-83,536$ \\
\hline MS 4790: 456 & nn. 85-90, 93 and 95, 537 nn. 97 and \\
\hline MS 6546: 470 & $99-115,538$ nn. $116-20,123,125-27$, \\
\hline MS 6640: 477 & $129-31$ and $133-34,539$ nn. $141-43$, \\
\hline MS 6659: 480 & $145-46$ and 151 \\
\hline MS 6972: 480 & Ms. Coll. 591: 509 n. 4, 510 fig. 1 \\
\hline MS 7084: 477 & \multirow{7}{*}{$\begin{array}{l}\text { Kane MS 33: } 482 \\
\text { Kane MS 43: } 480 \\
\text { Kane MS 48: } 482 \\
\text { MS Garrett 143: } 296 \text { n. } 1\end{array}$} \\
\hline MS 10190: 470 & \\
\hline MS 12200: 473 & \\
\hline MS 12260: 470 & \\
\hline MS 12262: 470 & \\
\hline MS 12263: 470 & \\
\hline MS 12264: 470 & \\
\hline MS 12269: 472 & Rome, Biblioteca Casanatense \\
\hline MS 12283: 480 & MS 969: 269 \\
\hline
\end{tabular}


Manuscript Studies, Vol. 2 [2018], Iss. 2, Art. 8

\section{4 | Journal for Manuscript Studies}

MS 1730: 267-95, 267 n. 1, 267-68 n. 3, 268 n. 4, 269 n. 6, 270 fig. 1, 272 figs. 2-3, 273 fig. 4, 277 fig. 5, 277 nn. 17-21, 278 figs. $6-7,279$ n. 22 , 280 figs. $8-9$, 280 n. 23, 281 figs. $10-11,281$ n. 24 , $282 \mathrm{nn} .25-27,283$ figs. 12-14, 284

n. 28,285 figs. $15-16,285$ n. 29,286

n. 30, 287 figs. $17-18,288$ fig. 19,288

n. 31, 289 fig. 20, 290 figs. 21-22, 291

fig. 23, 291 n. 32, 292 fig. 24,293

fig. 25

MS 2206: 421 n. 75

Rome, Biblioteca Nazionale Centrale

VE 1006: 470

VE 1190: 469

VE 1347: 470

VE 1348: 470

VE 1357: 470

VE Sessor 590: 470

San Lorenzo de El Escorial, Real Biblioteca del Monasterio de El Escorial

Y/III/6: 542, 558 n. 31

San Marino, Huntington Library

HM 31151: 471

Siena, Biblioteca Comunale degli Intronati MS D V 13: 405 n. 37, 418, 420 fig. 2

Stockholm, Nationalmuseum

NMB 1960: 479

Stuttgart, Landesbibliothek

Theol. \& Phil. Fol. 341: 472
Tokyo, Senshu University

MS 7: 467, 467 n. 95, 482

Vatican City, Biblioteca Apostolica Vaticana Stamp. Barb. A VIII 18,: 403, 408 n. 51, 420

Vat. et. 1: 400, 400 n. 25, 409-10, $410 \mathrm{n}$. 59, 421 n. 75, 422, 424 fig. 5, 425, 425 n. 81,426

Vat. et. 2: 400, 400 n. 25, 401, 409, 425-26

Vat. et. 5: 407

Vat. et. 10: 425 n. 82

Vat. et. 15: 406, 406 n. 39, 425

Vat. et. 16-18: 425 n. 82

Vat. et. 25 : $406-7$ n. 44,407

Vat. et. 35: 400, 406, 406 nn. 39-40, 409, 409 n. 53, 421, 422 fig. 3, 425 n. 82, 426

Vat. et. 40: 426

Vat. et. 42, 49, 52, and 57: 425 n. 82

Vat. et. 66: 400, 402-6, 406 n. 39, 407 n. 45, 408 n. 51, 409, 411, 418, 419 fig. 1, 423 n. 80,425 n. 82,426

Vat. lat. Ms. 2648: 269

Vat. lat. Ms. 3978: 269

Vat. lat. Ms. 5092: 269

Vat. lat. Ms. 6177: 398 n. 15, 401 n. 29

Vat. lat. Ms. 6178: 398 n. 16

Vaticano Rossiano 865 MS Vat. Ross 865:

400, 400 n. 25, 409, 422, 423 fig. 4, 426

Vatican City, Archivio Segreto Vaticano

AA., Arm. I-XVIII, no. 2953: $395 \mathrm{nn}$.

7-8, 396 nn. 9-10, 397 nn. 13-14, 398

nn. $17-18,404$ n. 34,416 n. 72 